\title{
Otobiyografik Hatırlamanın Duygu Düzenleme İşlevinin Íncelenmesi
}

\author{
Sezin Öner ${ }^{1}$ \\ Kadir Has Üniversitesi
}

\author{
Sami Gülgöz ${ }^{2}$ \\ Koç Üniversitesi
}

\begin{abstract}
Özet
Bellek ve duygusal süreçlerin ilişkisi alanyazında geniş yer tutmaktadır. Bu iki kavramı bütünsel bir bakışla incelemeyi amaçladığımız bu çalışmada otobiyografik belleğin duygu düzenleme işlevine odaklanılmıştır. Üç ayrı gruptaki katılımcılara, üzüntü, öfke veya mutluluk uyandıracak anılar hatırlatılmış ardından da bir yönerge verilmeden herhangi bir anı hatırlamaları istenmiştir. Katılımcılar ayrıca anı özelliklerini belirtmişler ve duygu düzenleme stratejilerini değerlendirmişlerdir. Hatırlamadan önce ve sonra katılımcıların nasıl hissettikleri de sorulmuştur. Bulgulara bakıldığında, duygusal etkisi yüksek anı hatırlayan olumsuz anı grubu katılımcılarının, yönergesiz hatırlama sonrasında duygu durumlarını belirgin olarak olumlulaştırdığı görülürken, bu değişimin üzüntü ve öfke gruplarında farklı anı özellikleri tarafından yürütüldüğünü saptanmıştır. Üzüntü grubunda yönergesiz anının duygusal yoğunluğunun, öfke grubunda ise anının öneminin duygu değişimine aracı olduğu gösterilmiş̧tir. Bulgular, otobiyografik hatırlamanın duygu düzenleme işlevi bağlamında tartışılacaktır.
\end{abstract}

Anahtar kelimeler: Otobiyografik bellek, duygu düzenleme, işlevsel yaklaşım, bilişsel yeniden değerlendirme

\begin{abstract}
In this study, we aimed to investigate emotion regulation function of autobiograhical remembering within an integrative perspective. We asked participants to recall sadness, anger and happiness related events for emotion induction, then they recalled any random memory that came to their mind. In the latter remembering experience. Pre- and post-report emotionality ratings and phenomenological features of the recall were examined to test whether subsequent recall served to upregulate positive emotions. Only in sadness and anger memory groups who recalled memories with high emotional impact reported more positive emotions after subsequent remembering. Also, we found distinct mechanisms by which sadness and anger groups used for emotion regulation such that for the sadness group whereas the emotional intensity accounted for the role of upregulation, for the anger group, importance of the event predicted enhanced positivity. Findings are discussed in the context of the emotion regulation function of autobiographical remembering.
\end{abstract}

Keywords: Autobiographical memory, emotion regulation, functional perspective, cognitive reappraisal

Yazışma Adresi: ${ }^{1}$ Dr. Öğr. Üyesi Sezin Öner, Kadir Has Üniversitesi, Psikoloji Bölümü, Kadir Has Caddesi Cibali - Fatih / İstanbul, sezin.oner@khas.edu.tr, ORC-ID: 0000-0001-8124-3554

${ }^{2}$ Prof. Dr., Koç Üniversitesi, Psikoloji Bölümü, sgulgoz@ku.edu.tr, ORC-ID: 0000-0002-1262-2347

Gönderim Tarihi: 07.07.2017

Kabul Tarihi: 18.07.2019 


\section{Otobiyografik Hatırlamaya İşlevsel Yaklaşım}

Kişilerin yaşamları boyunca deneyimledikleri olaylar ile kendiliklerine ilişkin bilgileri kapsayan uzun dönemli hafiza sistemi otobiyografik bellek olarak adlandırılmaktadır (Tulving, 1986). Alanda yapılan çalışmalar özellikle hangi kişisel anıların hatırlandığına ve bu anıların niteliğine odaklanmıştır. Son on yılda yapılan araştırmalar ise otobiyografik belleğin kişilerin hayatındaki işlevselliği üzerinde durarak, farklı amaçlara hizmet eden hatırlama süreçlerinin anıların hatırlanma niteliklerini nasıl etkilediğini incelemeye başlamıştır (Alea ve Bluck, 2003; Bluck, Alea, Habermas ve Rubin, 2005). $\mathrm{Bu}$ bağlamda hatırlamanın benlik, sosyal ve yönlendirici olmak üzere üç temel işlevinden bahsedilmektedir. Benlik işlevi, tema ve amaçlar çerçevesinde tutarlı olan anıları hatırlamanın kişilerin kendilik algılarındaki tutarlılığ1 sağlamaya yönelik olduğunu vurgulamaktadır (Bluck ve Habermas, 2000). Sosyal işlev ise kişisel anıların paylaşılmasının hatırlama ile mümkün olduğunun altını çizerek anıların nasıl hatırlandığının kişilerarası ilişkilerin gelișmesi, sürekliliği ve genel olarak düzenlenmesinde etkili rol oynadığını öne sürmektedir (Alea ve Bluck, 2003). Üçüncü olarak da kişilerin ileriye yönelik tutum ya da davranışlarını belirlerken geçmiş yaşantılarından yararlandıkları vurgulanmış ve bu bağlamda hatırlamanın yönlendirici işlevinin üzerinde durulmuştur (Pillemer, 2003).

Özellikle duygu yükü olan anıların incelenmesinde anının duygu yoğunluğuna ve ne denli olumlu ya da olumsuz olduğuna bağlı olarak bellek süreçlerindeki farklılıklar üzerinde durulmuştur. Duygu değerliği açısından bakıldığında, kişilerin olumlu anıları hatırlamaya daha yatkın oldukları hem ipucu sözcük ile hem de serbest hatırlama ile geri getirilen anılarla yapilan çalışmalarda görülmüştür (Demiray, Gülgöz ve Bluck, 2009; Rubin ve Berntsen, 2003). Bu durum olumlu an1ları hatırlamanın kişilerin hem motivasyonlarını hem de olumlu benlik algılarını desteklediği ile ilişkilendirilmiştir (Conway, 2005; Rasmussen ve Berntsen, 2009). Duygusal yoğunluğun otobiyografik hatırlama üzerindeki etkisine bakıldığında da kodlama esnasında duygusal yoğunluğun yüksek olduğu anıların, hatırlama esnasında da yoğun duygularla, oldukça canlı bir biçimde ve yeniden yaşıyormuş hissi yaratarak hatırlandığı belirtilmiştir (Talarico, LaBar ve Rubin, 2004). Ayrıca yoğun hatırlanan bu anıların kişilerin önemli gördüğü, bir anlam yüklediği ya da yaşamları için belirgin sonuçları olan anılar olduğu görülmüştür. Benlik ve yaşam öyküsü tanımlayıcı olma özelliği bulunan bu anıları hatırlanmanın kişilerin yaşamlarında temel rolü olduğu düşünülmektedir (Bluck ve Habermas, 2000).

Olumsuz duygu yüklü anıların hatırlanmasının ise yoğun duygularla hatırlanan bu yaşantılardan alınan ders- lerin kişilerin karar ve davranışlarını belirlemede önemli bir etkisi olduğu görülmüş ve bu tür anıların kişilerde yönlendirici bir etkisi olduğu vurgulanmıştır (Pillemer, 2003, Rasmussen ve Berntsen, 2009). Travmatik yaşantıların hatırlanmasında, olaya ilişkin detayın daha çok istemsiz olarak, olay sırasındaki çevresel detayların ise istemli olarak hatırlandığı görülmüştür. Olay detayları istemsiz hatırlama ile çok canlı ve belirgin olarak geri çağrılabilse de istemli hatırlama oldukça dağınıktır. Bu bağlamda, istemsiz hatırlamanın aslında anının zihindeki bütünleşik temsiline hizmet eden bir bellek mekanizması olduğu düşünülmektedir. Belleğin işlevsel yaklaşımları bu örüntüyü açıklarken travma sonrası uyum sürecine odaklanmış ve hatırlama biçiminin bireylerin tutarlılık sağlamaya yönelik çabasını yansıttığını öne sürmüştür. Her ne kadar teorik olarak tutarlı bir yaklaşım söz konusu olsa da önermeler deneysel olarak çok az çalışma ile test edilmiştir (Rasmussen ve Berntsen, 2009; Waters, Bauer ve Fivush, 2014). $\mathrm{Bu}$ çalışmalarda, katılımcılara hayatlarına yön verirken hatırladıkları anılar sorulduğunda, belirtilen anıların ağırlıklı olarak olumsuz olmakla beraber oldukça kolay erișilebildiği, canlı ve duyusal imgelem açısından zengin bir şekilde hatırlandığı gözlenmiştir. Öte yandan, bu çalışmalar kapsamında, benlik ve sosyal işlevleri de belirleyen öğeler incelenmiş ve bu işlevlerin daha çok olumlu, yüksek yoğunluklu, istemli olarak sık hatırlanan anılar tarafindan sağlandığına dair bulgular rapor edilmiştir. Olumlu anıların duygusal yoğunluğunun, anıların bellek sistemindeki belirginliğini artırarak kişilerin bireysel ve sosyal yaşantılarını düzenlemelerine destek olduğu düşünülmüştür (Pasupathi, 2003; Rasmussen ve Berntsen, 2009).

Otobiyografik hatırlamanın hem işlevinin hem de niteliğinin kişinin duygu durumundan etkilendiği kadar, duygu durum da bellek süreçlerinden etkilenebilmektedir. Buna ilişsin olarak alanyazında hatırlamanın duygu düzenleme işlevi vurgulanmıştır (Raes ve ark., 2003; Rasmussen ve Berntsen, 2009). Duygu düzenleme otobiyografik belleğin temel işlevi olmayabilir, ancak benlik, sosyal ve yönlendirici gibi birincil işlevlerin önemli bir parçası olarak kabul edilmektedir. Buradaki temel anlayış, duygu düzenleme süreçlerinin kişinin kendini iyi hissetmesine yönelik olarak işlediği ve otobiyografik hatırlamanın da bu amaca yönelik kullanılacağı doğrultusundadır (Alea ve Bluck, 2007; Rasmussen ve Berntsen, 2009). Örneğin, kişi kendisini kötü hissettiğinde bu olumlu deneyimlerini hatırlayarak içinde bulunduğu olumsuz duygu durumdan kurtulmaya gayret edecektir. Başka bir olasılık olarak duygu düzenlemenin sosyal ilişkilerdeki rolü düşünülebilir. Kişiler kendileri için önemli olan ilişkilerini koruyabilmek adına sorunlara dair olumsuz anıları değil de ilişkilerini besleyecek olan olumlu anıları hatırlamaya yönelebilirler. Verilen örneklerde de göründüğü üzere, genel olarak kişilerin olumlu 
duyguları artırmaya ya da sürdürmeye ve olumsuz duyguları azaltmaya eğilimli olduğu öne sürülmekte (Tamir, Ford ve Gilliam, 2013) ve bu açıdan hatırlamanın oldukça önemli bir rolü olduğu vurgulanmaktadır.

Duygu düzenleme süreçlerini otobiyografik bellek kapsamında inceleyen çalışma sayısı oldukça azdır. $\mathrm{Bu}$ doğrultuda, yakın zamanlı bir araştırmada direkt olarak duygu düzenleme işlevini test etmeyi amaçladık (Öner ve Gülgöz, 2017). Bu çalışmada, katılımcılara anı hatırlama yöntemi ile üzgün veya öfkeli hissedecekleri an1lar ya da duygu durumlarını değiştirmeyecek nötr anılar hatırlatıldı. Ardından da herhangi bir anı hatırlamaları istenildi. Üzgün ve öfkeli anı hatırlayan, olumsuz duygu durum gruplarında daha sonra hatırlanan anı özelliklerinin nötr anı grubuna göre belirgin olarak farklılaştığını gözlemlendi. Psikolojik açıdan yakın hissedilen, bugün olmuş gibi hatırlanan (psychologically close), öfke ve üzüntü içeren anılar anlatan katılımcılar, sonraki aşamada daha olumlu, duygusal olarak yoğun ve canlı anılar hatılladılar. Hatta özellikle öfke anısı grubunda, ilk anı ne kadar canlı hatılandıysa, öfke duygusunu azaltmaya yönelik hatırlanan ikincil anının da o kadar pozitif ve canlı olduğu görüldü. Olumsuz anı gruplarında görülen duygu durumu tersine çevirmeye yönelik mekanizmanın aksine; kontrol grubunda daha çok duygu tutarlılığının korunduğu görülmüștür. Bu bağlamda bulgular belleğin duygu düzenleme işlevini destekler niteliktedir. Kişiler olumsuz hissettikleri durumlarda otomatik olarak otobiyografik belleği kullanarak daha iyi hissetmeye çalı̧̧maktadırlar. Bu durumun özel bir bilişsel çaba gerektirmeden otomatik gerçekleşmesi de oldukça anlamlıdır. Çünkü gündelik hayat akışı içinde bireyler duygularını kontrol etmek için belirli bir zaman ayırmasalar da bellek daha gizil bir mekanizma ile olumsuz duyguları azaltmaya ve düzenlemeye yönelik bir şekilde kişilere destek olmakta (Mauss, Bunge ve Gross, 2007; Koole, 2009) ve bireylerin ruhsal iyi hallerini korumalarına yardımcı olmaktadır (Watson ve Dritschel, 2015).

Var olan bulgulardan yola çıkarak, bu çalışmada birincil olarak otobiyografik hatırlamanın duygu düzenlemedeki rolüne odaklanılmıştır. Ayrıca, alanyazındaki duygu düzenleme etkinliğinde bireysel farklılıklar olduğuna dair bulguları göz önüne alarak, kullanılan stratejilerin hatırlama süreçlerinin işlevselliğini nasıl etkileyebileceğini anlamanın önemli olduğu düşünülmüştür.

\section{Duygu Düzenleme Süreçlerine Genel Bakış}

Duygu düzenleme kavramının tanımlanması ve incelenmesi ile ilgili olarak farklı yaklaşımlar mevcut olmakla beraber genel kabul gören anlayışa göre duygu düzenleme, yeni bir duygusal tepki başlatılmasını ya da devam eden duygusal tepkinin değiştirilmesine yönelik süreçlere karşıllık gelmektedir. Duygusal tepki, fizyolojik, bilişsel ya da davranışsal bağlamda değiş̧irilebilir, otomatik ya da kontrollü olabilir (Koole, 2009), bilinçli ya da bilinçdışı gerçekleşebilir (Bargh ve Williams, 2007) ve düzenleme, duygusal süreci etkilemeye farklı zaman noktalarında başlayabilir (Gross, 2002).

Gross (2002) duygu düzenleme stratejilerini beş kategoride toplamıştır. Bu stratejiler duygu oluşum sürecine etki zamanlarına göre birbirlerinden ayrılmaktadır. Durum seçme ve durum değiştirme, beklenen bir duyguyu değiştirmek adına o duygunun oluşacağı koşulları düzenlemeye yönelik davranışları içerir. Olay koşullarının düzenlenemediği durumlarda, kişi, olaya yönlendireceği dikkat düzeyini değiştirebilir ya da bilişsel yeniden değerlendirme (cognitive reappraisal) ile olay1 yorumlama biçimine müdahale edebilir. Bunun mümkün olmadığı koşullarda ise var olan duyguya verilecek fizyolojik, duygusal ya da davranışsal tepki değiştirilebilir (Gross, 2002; Gross ve Thompson, 2007). Bu stratejilerin zaman bağlamında ayrılması anlamlıdır, çünkü, uyarılan herhangi bir duygu hiçbir müdahale olmadığı durumda giderek şiddetini artırrr. Bu nedenle duygu düzenleme stratejileri ne kadar erken etkinleştirilirse hem duygusal süreçlerinin kontrolü kolaylaşır hem de kişilerin bu kontrol sürecinde deneyimleyebilecekleri "yan etkiler" azalır (Sheppes ve Gross, 2011).

$\mathrm{Bu}$ alanda yapılan çalışmalar da erken etkinleştirilen duygu düzenleme stratejilerinin geç olanlara göre daha etkili olduğu ve uzun dönemdeki etkisinin daha kalıcı olduğunu göstermiştir. Örneğin, katılımcılara olumsuz duygular içeren kısa filmler izlettirilerek bir grup katılımcıya izledikleri filmde olayları farklı yorumlamaları (bilişsel yeniden değerlendirme yönergesi), bir grup katılımcıya ise hissettiklerini davranışlarına yansıtmamaları (baskılama yönergesi) söylenmiştir. Sonuçlara bakıldığında, davranışsal tepkilerini bastırmaya çalışan gruptaki katılımcıların öznel değerlendirmelerinde bir düşüş gözlense de kalp atımı, deri iletkenliği gibi heyecanlanma ile değişen fizyolojik tepkilerinde artı̧ gözlenmiştir. Öte yandan, izledikleri filmi farklı yorumlamaya çalışan bireylerin hem fizyolojik tepkileri hem de olumsuz duygu değerlendirmeleri anlamlı olarak azalmıştır (Gross ve Levenson, 1997).

Bilişsel yeniden değerlendirme ve bastırmanın etkinliğini inceleyen bir başka çalışmada ise çiftlerden sorun yaşadıkları bir konu hakkında tartışmaları istenmiş ve bu tartışmaya dair ne hissettikleri ve ne hatırladıkları belirli bir aradan sonra sorulmuștur. Tartışma deneyiminin ardından olumsuz duygulardaki düşüş bilişsel değişim grubunda daha fazla olmuş ve yine bu gruptaki çiftlerin tartışmaya dair daha doğru ve sayıca fazla detay hatırladıkları görülmüştür (Richards ve Gross, 2000, 2003). Denson, Moulds ve Grisham (2012) ise olumsuz 
duygudan ziyade yalnızca öfke duygusuna odaklanarak, bilişsel yeniden değerlendirme ve baskılama ile beraber dikkat yayılımının (attentional deployment) duygu düzenlenmesine olan etkinliğini incelemiştir. Temel kanı ile tutarlı olarak daha erken uygulanan dikkat yayılımı ve bilişsel yeniden değerlendirmenin baskılamaya göre daha kısa sürede duygu değişimi gösterdiği bulunmuştur.

Tüm bu istemli etkinleştirilen duygu düzenleme stratejilerinin yanı sıra istemsiz, daha otomatik gerçekleşen düzenleme stratejilerinin etkinliği de yakın zamanlarda tartışılmaya başlanmıştır. Homeostazi yani iç denge yaklaşımı üzerine kurulan bu yaklaşım temelde alışkanlık haline gelmiş uyaran-tepki ilişkilerine odaklanmış ve tanıdık durumlarda etkin olan duygunun o anki amaçlarla tutarlı olarak düzenleneceğinin üzerinde durmuştur. Örneğin, görsel bakış açısındaki değişiminin önemli bir bilişsel değişim yöntemi olduğu fikrinden yola çıkarak araştırmalarda, kişilerin anılarını hatırlarken oluşabilecek olumsuz duyguları azaltmak için aktör bakış açısını bırakıp gözlemci bakış açısını aldıkları görülmüştür (Mauss, Bunge ve Gross, 2007). Otomatik duygu düzenleme, dikkat düzeyinde de gerçekleşebilmektedir. Özellikle kaygı düzeyi yüksek bireylerin, herhangi bir tehdit olmadığı durumlarda dahi dikkatlerini olumsuz uyarıcılara yönlendirdikleri görülmüştür. Bu durum, işlevsel olmasa bile bu bireylerde önlem alarak güvence hissi yarattığından olumsuz duygularını kontrol etmelerine yardımcı olmaktadır (Werner ve Gross, 2013).

Otomatik duygu düzenleme alanyazında görece yeni çalışılmaya başlayan bir olgu olmakla beraber, yapılan çalışmalar kişilerin amaçları ve beklentileri doğrultusunda farkında olmadan duygusal durumlarını değiştirmeye yönlendiklerini doğrulamıştır (Koole ve Rothermund, 2009; Schwager ve Koole, 2013). Örneğin, iki grup katılımcıya sırasıyla tartışmaları ya da uzlaşmaları beklenen durumlara girecekleri söylendiğinde, ilk grup daha öfke içerikli olarak değerlendirilen müziği dinlemeyi seçerken, diğer grubun daha sakin içerikli müziği dinlemeyi seçtiği bulunmuştur. Bu bulgular, amaca (uzlaşma ya da tartışma) yönelik olarak kişilerin duygusal-bilişsel sistemlerini hazırlama davranışı olarak değerlendirilmektedir (Tamir ve ark., 2013). Başka bir çalışmada da olumsuz anıları hatırlamanın otomatik duygu düzenleme süreçlerine etkisi incelenmiş ve özellikle yoğun duygusal içerikli ve etkisi halen sürmekte olan, henüz üzeri kapanmamış anıların hatırlanmasından sonra bireylerin olumlu uyaranlara daha duyarlı olduğu gözlenmiştir (Koole ve Fockenberg, 2011).

\section{Amaç ve Kapsam}

Otobiyografik bellek ve duygu süreçleri ilişkisinin alanyazında sıkça incelendiği görülmektedir (Hol- land ve Kensinger, 2010). Bu karşılıklı ilişki, işlevsel bellek yaklaşımlarınca kuramsal olarak ele alınmış olsa da özellikle son yıllarda duygu düzenleme işlevi üzerine yapılan deneysel çalışmaların sayısı artmaktadır (örn., Foland-Ross, Cooney, Joormann, Henry ve Gotlib, 2012; Öner ve Gülgöz, 2017; Wisco ve Nolen-Hoeksema, 2010). Öte yandan, duygu düzenleme alanında yapılan çalışmalarda hatırlama daha çok kişilerde bir duygu durum oluşturma amacıyla kullanılmış ve hatırlama sürecinin niteliksel boyutu üzerinde durulmamıştır. $\mathrm{Bu}$ çalışmada, iki alanı bütünsel bir çerçevede ele alarak belleğin duygu düzenleme işlevinin incelenmesi amaçlanmış, aynı zamanda da duygu düzenlemede kullanılan yöntemlerden olan bilişsel yeniden değerlendirme stratejisinin, hatırlamanın işlevsel işleyişi üzerindeki etkisine bakılmıştır.

$\mathrm{Bu}$ çalışmada katılımcılardan öncelikle olumsuz (öfke ya da üzüntü uyandıran) ya da olumlu (mutluluk uyandıran) anılar hatırlamaları istenecek, ardından herhangi bir anı (yönergesiz anı) hatırlatılarak ve bu anıya dair anı özellikleri incelenecektir. Yönergesiz anı hatırlamadan önce ve sonraki duygu durum değişimi incelediğinde ise hem anının duygusal etkisinin hem de bilişsel yeniden değerlendirme becerisinin duygu değişiminde etkili olması beklenmektedir. Bilişsel yeniden değerlendirme stratejilerini etkin bir biçimde kullanan bireylerin yönergesiz anı sorulduğunda otomatik/gizil duygu düzenleme süreçlerinden faydalanmaları, bu doğrultuda daha olumlu, yoğun ve etkili anılar hatırlayarak hatırlama sonrasında daha olumlu hissetmeleri beklenmektedir.

\section{Yöntem}

\section{Örneklem}

Koç Üniversitesi deney katılım havuzu aracılığı ile duyurulan araştırmaya 100'ü kadın (\%69.4), 44'ü erkek (\%30.6) olmak üzere 144 öğrenci katılmıştır. Örneklemin yaş ortalaması 22.48, standart sapması 1.67 olarak hesaplanmıştır. Katılımcılar, rastlantısal seçilim ile üzüntü, öfke ve mutluluk uyaran anılar hatırlamak üzere üç ayrı gruba atanmıştır.

\section{Veri Toplama Araçları}

Anı Özellikleri Ölçeği (Autobiographical Memory Questionnaire). Rubin, Schrauf ve Greenberg (2003) tarafından geliştirilen ölçek otobiyografik anıların fenomenolojik özelliklerini birkaç farklı boyutta değerlendirmektedir. Otobiyografik bellek çalışmalarında sıkça kullanılan bu ölçeklebelirlenen boyutlar, faktör puanları oluşturulmadan birer madde ile değerlendirilmektedir. Türkçe uyarlaması Gülgöz ve Rubin (2001) tarafindan yapılan ölçeğin, Türk örneklemlerinde de geçerli olduğu görülmüştür. 
Duygusal yoğunluk, yeniden yaşama hissi, görsel ve işitsel imgelem, olumluluk-olumsuzluk (valence) bu çalışmada odaklanılan ana boyutlardır. Olumluluk - olumsuzluk dişındaki her boyut 1 - 7 arasında değerlendirilmiştir. Olumluluk - olumsuzluk maddesi ise -3 (çok olumsuz) ve +3 (çok olumlu) arasında derecelendirilmiştir.

Anı özellikleri dışında olayın gerçekleştiği gerçek zamandan bağımsız olarak olayın ne kadar önce gerçekleşmiş olduğuna dair öznel değerlendirmeye karşılık gelen öznel zaman algısı (subjective temporal distance) da sorulmuştur. Öznel zaman algısı, bir psikolojik yakınlık - uzaklık (psychological distance) değişkeni olup (Liberman, Sagristano ve Trope, 2002) anı temsilinin benlik ile ne denli ilişkili olduğunun da bir göstergesi olarak görülmekte ve aynı zamanda anının duygusal etkisinde rol oynayacağı öne sürülmektedir (Van Boven, Kane, McGraw ve Dale, 2010). Bu bağlamda, katılımc1lar yönergesiz anıy "100" (Olay daha dün olmuş gibi hissediyorum) ve "0" (Olayın üzerinden çok zaman geçmiş gibi hissediyorum) arasında değerlendirmiştir.

Duygu Uyarım Kontrolü. Hatırlamanın kişilerin duygu durumunu değiştirmede ne denli etkin olduğunu değerlendirebilmek için, ilk hatırlama aşamasından sonra "Şu an nasıl hissediyorsunuz?" sorusu katılımcılara sorulmuştur. Yönergesiz anının duygu değişimine etkisini incelenmek amacıyla, yönergesiz hatırlamadan sonra da aynı soru sorulmuştur. Katılımcılar her bir duygu durum sorusunu "1" (çok olumsuz) ve "7" (çok olumlu) ekseninde değerlendirmişlerdir.

Duygu Düzenleme Ölçeği (Emotion Regulation Questionnaire). Gross ve Thompson (2003) tarafından geliştirilen bu ölçeğin duygu düzenleme alanında en yaygın kullanılan araç olduğu bilinmektedir. Temel olarak bireylerin duygusal süreçlerini yönetirken genellikle hangi stratejileri kullanmaya yatkın olduğunu değerlendiren 10 soruluk bu ölçekte bilişsel yeniden değerlendirme (6 madde) ve baskılama (4 madde) stratejilerine odaklanılmıştır. Türkçe uyarlaması ile geçerlik ve güvenirlik çalışması Yurtsever (2004) tarafından yapılan ölçeğin bu çalışmadaki güvenirlik değerleri de ölçeğin özgün formuyla tutarlı bulunmuştur (bilişsel yeniden değerlendirme alt ölçeği, Cronbach alfa $=.84$; baskılama alt ölçeği, Cronbach alfa $=.70)^{1}$.

\section{İşlem}

Katılımcılar araştırma laboratuvarına üçer kişilik gruplarda alınmış ancak araştırmayı bilgisayar başında bireysel olarak tamamlamıştır. Rastlantısal olarak farklı anı gruplarına atanan katılımcılardan üzüntü anısı gru- bundakilerden iki üzüntü anıs1, öfke anısı grubundakilerden iki öfke anısı, mutluluk anısı grubundakilerden de iki mutluluk anısı anlatmaları istenmiştir. Ardından, katılımcılar iki anı için de anının ne denli olumlu ya da olumsuz olduğu, ne denli yeniden yaşama hissi, görsel imgelem ve duygusal yoğunluk ile hatırlandığı gibi anının niteliksel özelliklerini değerlendiren soruları yanıtlamışlardırr. Duygu uyarımının etkili olup olmadığını değerlendirmek için bu ilk hatırlama aşamasından sonra katılımcilardan ayrica o an nasil hissettiklerini olumsuzluk - olumluluk ekseninde belirtmeleri ve ardından hatırladıkları herhangi bir anıyı (yönergesiz anı) anlatmaları istenmiştir. Katılımcılar Otobiyografik Bellek Özellikleri Ölçeği üzerinde yönergesiz anının niteliksel özelliklerini değerlendirerek bu anıya ilişkin öznel zaman algısını belirtmişlerdir. Katılımcılar yönergesiz anıdan sonra da duygu durumlarını belirtmişlerdir. Katılımcılar Duygu Düzenleme Ölçeğini tamamladıktan sonra araştırma sonlandırılmıştır. Çalışma sonunda katılımcılara yazılı bir geri bildirim verilmiş; katılımları karşılığında deney kredisi almışlardır.

\section{Bulgular}

\section{Duygu Yüklü Anı Özellikleri}

İlk aşamada hatırlanan anıların olumsuzluk olumluluk dışındaki özelliklerinin olası etkisini kontrol etme amacıyla öncelikle üzüntü, öfke ve mutluluk içerikli anı özellikleri incelenmiştir. Temel etkilere bakıldığında yalnızca olumsuzluk - olumluluk bağlamında anlamlı bir etki bulunmuştur, $F(2,144)=85.21, M S E=$ $124.45, p<.001, \eta p^{2}=.55$. Üzüntü (Ort. $\left.=-.89, S=1.39\right)$ ve öfke (Ort. $=-.77, S=1.22$ ) grupları birbirinden farklılaşmazken, her iki grup anıları, mutluluk anısına (Ort. $=1.97, S=0.94$ ) göre daha olumsuz değerlendirilmiştir (bkz. Tablo1).

Yönergesiz anı özellikleri benzer şekilde incelendiğinde ise gruplar arasında anlamlı bir farklılık ne olumsuzluk - olumluluk bağlamında ne de diğer anı özellikleri bağlamında farklılaşmamıştır. Bu örüntü, ilk hatırlama aşamasından sonraki duygu ifadeleri kontrol edildiğinde de değişmemektedir. Tablo 2 anı gruplarına ilişkin yönergesiz anı özelliklerinin ortalama değerleri ve standart sapmalarını göstermektedir.

\section{Yönergesiz Hatırlama Önce ve Sonrası Duygu Durum Değerlendirmeleri}

Hatırlanan otobiyografik anıların hedeflenen şekilde olumsuz - olumlu duyguları uyandırıp uyandırmad1ğını test etmek amacıyla katılımcıların ilk hatırlamadan

\footnotetext{
1 Bilişsel yeniden değerlendirme kavramsal süreçler üzerinden bir düzenleme işlevi sağlarken, baskılama etkisi ağırlıklı olarak fizyolojik değişkenlerde ortaya konmaktadır. Bu nedenle temel olarak bilișsel yeniden değerlendirmeye odaklanılmıș ancak baskılama alt ölçeği de ölçek bütünlüğünü korumak adına verilmiştir.
} 
Tablo 1. Duygu Uyandıran İlk Hatırlama Anı Özellikleri ve Duygu Değerlendirmeleri

\begin{tabular}{lccc}
\hline & Üzüntü Anısı Grubu & Öfke Anısı Grubu & Mutluluk Anısı Grubu \\
\cline { 2 - 4 } & Ort. $(S)$ & Ort. $(S)$ & Ort. $(S)$ \\
\cline { 2 - 4 } Olumsuzluk - Olumluluk & $-0.89(1.40)$ & $-0.77(1.22)$ & $1.97(0.94)$ \\
Yeniden yaşama hissi & $4.85(1.56)$ & $4.72(1.28)$ & $5.21(1.36)$ \\
Duygusal yoğunluk & $4.43(1.49)$ & $4.27(1.54)$ & $4.67(1.42)$ \\
Görsel imgelem & $5.69(1.10)$ & $5.72(1.08)$ & $6.12(1.15)$ \\
& & & $5.57(1.33)$ \\
\hline Duygu Durum (1) & $3.08(1.18)$ & $3.02(1.04)$ & $4.43(1.66)$ \\
\hline
\end{tabular}

Not. ${ }^{\text {a} Y o ̈ n e r g e s i z ~ h a t ı r l a m a d a n ~ o ̈ n c e k i ~ d u y g u ~ d e g ̆ e r l e n d i r m e s i, ~}{ }^{\text {b} Y o ̈ n e r g e s i z ~ h a t ı r l a m a ~ s o n r a s ı ~ d u y g u ~ d e g ̆ e r l e n d i r m e s i ~}$

sonra nasıl hissettikleri tek yönlü varyans analizi ile incelenmiştir. Anı grubunun kişilerin nasıl hissettiği üzerinde anlamlı bir etkisi olduğu gözlenmiştir, $F(2,144)=$ 66.67, $M S E=88.00, p<.001, \eta p^{2}=.283$. Gruplar aras1 farklar incelendiğinde, üzüntü (Ort. $=2.98, S=1.06)$ ve öfke (Ort. $=3.07, S=1.02)$ gruplarının birbirinden farklılaşmadığ1; mutluluk (Ort. $=5.50, S=1.34$ ) grubunun ise diğer iki gruptan daha olumlu hissettiği görülmüştür.

Yönergesiz anı aşamasının ardından katılımcıların nasıl hissettiği incelendiğinde ise gruplar arası anlamlı bir fark gözlenmemiştir, $F(2,144)=0.06, M S E=0.15$, $p=.94, \eta p^{2}=.01$. Yönergesiz anıyı hatırlamadan önce olumsuz hissettiğini belirten üzüntü (Ort. $=4.63, S=$ 1.61 ) ve öfke (Ort. $=4.54, S=1.64$ ) gruplarının, yönergesiz hatırlama sonrasında duygu durumlarını mutluluk (Ort. $=4.52, S=1.70)$ grubundan farksız hale getirdiğini ve dolayısıyla da bir duygu düzenleme mekanizmasının işlediğini göstermektedir.

\section{Yönergesiz Hatırlama ile Duygu Durum Değișiminin Anı Gruplarına Göre İncelenmesi}

Üzüntü, öfke ve mutluluk anısı gruplarındaki duygu durumun yönergesiz hatırlamadan önce ve sonrasındaki değişiminin anlamlı olup olmadığ incelenmiştir. Uygulanan iki yönlü karışık desen varyans analizinde yönergesiz hatırlama öncesindeki ve sonrasındaki duygu durum ilişkili değişken olarak, anı grubu ise bağımsız değişken olarak kullanılmıştır. Temel etkilere bakıldığında, duygu durumdaki değişimin hatırlama öncesi ve sonrasına bağlı anlamlı olarak farklılaştığ $=11.57, M S E=20.17, p<.01, \eta p^{2}=.08$ ve an1 grubu etkisinin de anlamlı olduğu bulunmuştur, $F(2,141)$ $=15.50, M S E=40.15, p<.01, \eta p^{2}=.18$. Hatırlama öncesinde (Ort. $=3.87, S=1.67$ ) daha olumsuz olarak ifade edilen duygu durumun, hatırlama sonrasinda (Ort. $=4.50, S=1.68$ ) daha olumlu yönde değişimi olduğu görülmektedir. Grupların duygu durum ifadelerine bak1ldiğındada mutluluk (Ort. $=5.00, S=1.64)$ grubunun üzüntü (Ort. $=3.83, S=1.15)$ ve öfke $($ Ort. $=3.57, S$ $=1.16$ ) gruplarına göre daha olumlu duygulanım ifade ettiği gözlenmiştir.

Bir sonraki aşamada, değişimin farklı anı gruplarında nasıl şekillendiği incelendiğinde, duygu durumun anı grubu ile etkileşim etkisinin de anlamlı olduğu gözlenmiştir, $F(2,141)=34.63, M S E=60.35, p<.01, \eta p^{2}$ $=.33$. Etkileşim etkisini daha iyi anlamak için yapılan analizlerde, her bir gruptaki yönergesiz hatırlama öncesi ve sonrası değișimin anlamlı olduğu görülmüştür. Ancak, değişimin yönü olumlu ve olumsuz anı gruplarında farkl1 yöndedir. Üzüntü (Ort. $=1.50, S=1.97)$ ve öfke (Ort. $=1.41, S=1.62$ ) anısı gruplarında duygu durumda olumluya doğru yükseliş eğilimi gözlenirken, mutluluk grubunda (Ort. $=-1.14, S=1.99$ ) bir düşüş gözlenmiştir. Ortalama ve standart sapmalar gruplar bazında detaylı olarak Tablo 1'de gösterilmektedir.

Duygu düzenleme mekanizmasının olumlu duyguları artırmaya yönelik işlediği gruplar arası değişimlerden görülmektedir. Bu durumun bilişsel yeniden değerlendirme ve yönergesiz anı özellikleri göz önüne aldığında nasıl değişeceği ise çift yönlü karma desen kovaryans analizi ile incelenmiştir. Bilişsel yeniden değerlendirme kontrol edilerek yapılan analizlerde, her ne kadar bilişsel yeniden değerlendirmenin kovaryans etkisi anlamlı çıkmasa da, bu değişkenin analize dahil edilmesi hatırlama öncesi ve sonrası duygu durumda olan değişimin etkisini ortadan kaldırmaktadır. Bunun dışında ise bulguların örüntüsü değişmemektedir. Şu haliyle, bilişsel yeniden değerlendirmenin etkisi yalın olarak anlamlı olmasa da 
Üzüntü Anısı Grubu

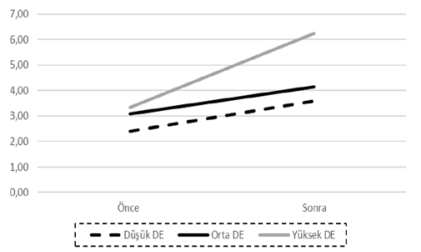

Şekil 1. Üzüntü Anısı Grubu - Duygusal Etki Gruplarına Göre Duygu Durum Değişimi

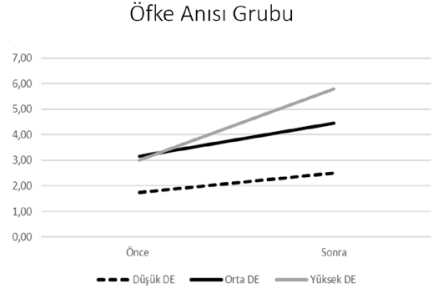

Şekil 2. Öfke Anısı Grubu - Duygusal Etki Gruplarına Göre Duygu Durum Değişimi

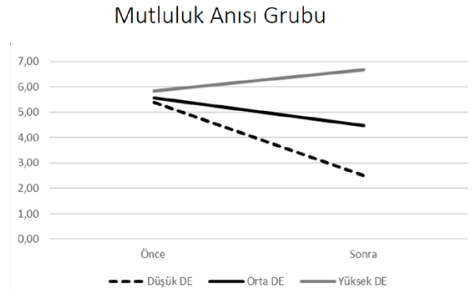

Şekil 3. Mutluluk Anısı Grubu - Duygusal Etki Gruplarına Göre Duygu Durum Değişimi

hatırlama süreçlerini etkileyerek dolaylı bir etkisi olduğuna işaret etmektedir. Bu etkiyi daha iyi anlayabilmek adına bir sonraki aşamada yönergesiz anı özellikleri incelenmiştir.

Yönergesiz anı incelenirken, önceki çalışmalarda kullanıldığı üzere anının duygusal etkisine de odaklanılmıştır. Yönergesiz anının öznel zaman algısı ve olumsuzluk-olumluluk ekseninde hesaplanan (Öner ve Gülgöz, 2017) etki değişkeninde ${ }^{2}$ negatif yüksek değerler çok olumsuz ve dün olmuş gibi hatırlanan yakın anıları temsil ederken, pozitif ve yüksek değerler ise çok olumlu ve dün olmuş gibi hatırlanan yakın anıları temsil etmektedir.

İki yönlü karmaşık desen varyans analizinde duygusal etki kovaryans olarak kullanılmıştır. Temel etkilere bakıldığında hatırlama öncesi ve sonrası değişim anlamlı değil iken $\left[F(2,140)=0.38, M S E=0.69, p=.53, \eta p^{2}\right.$ $=.01]$, anı gruplarının etkisi anlamlı bulunmuştur, $F(2$, $140)=29.66, M S E=52.98, p<.01, \eta p^{2}=.30$. Daha da önemlisi duygusal etkinin hatırlama kovaryans etkisi $\left[F(1,140)=64.55, M S E=115.31, p<.01, \eta p^{2}=.32\right]$ ve hatırlama öncesi ve sonrası duygu durum değişimi ile olan etkileşim etkisinin anlamlı olduğu görülmüştür, $F(1,140)=41.49, M S E=56.19, p<.01, \eta p^{2}=.23$.

Kovaryans etkisini anlayabilmek için duygusal etkinin rolü daha detaylı incelenmiştir. Ortalamanın bir standart sapma alt ve üst değerleri kesme sınırları kabul edilerek düşük, orta ve yüksek duygusal etki grupları oluşturulmuştur. Bu grupları bağımsız değişken olarak kullanarak üç yönlü karma desen varyans analizi uygulanmıștır. Duygu değişimi, $[F(1,135)=14.15, M S E=$ $21.35, p<.01, \eta p^{2}=.10$, an1 gruplar1, $[F(2,135)=18.99$, $\left.M S E=36.54, p<.01, \eta p^{2}=.22\right]$ ve duygusal etki düzeylerinin, $\left[F(2,135)=20.68, M S E=39.80, p<.01, \eta p^{2}=\right.$ .24], temel etkilerinin anlamlı olduğu görülmüştür. Aynı zamanda, duygu değişimi ve anı gruplarının etkileşimi, $\left[F(2,135)=21.72, M S E=32.76, p<.01, \eta p^{2}=.24\right]$, ile duygu değişimi duygusal etki düzeyinin etkileşimi de, $\left[F(2,135)=10.99, M S E=16.59, p<.01, \eta p^{2}=.14\right]$, anlamlı bulunmuştur.

$\mathrm{Bu}$ etkileşim etkilerini çözümleyebilmek için her bir duygusal etki grubu ve her bir anı grubu için tek yönlü varyans analizi (ANOVA) uygulanmıştır. Düşük duygusal etki grubunda, yönergesiz hatırlama öncesinden sonrasına duygu değişimi anlamlı değilken, orta ve yüksek duygusal etki gruplarında yönergesiz hatırlama sonrasında duygu durumda belirgin bir olumlulaşma gözlenmiştir. Her bir anı grubu için benzer analizler yapıldığında ise olumlu ve olumsuz anı gruplarında zit örüntülerin ortaya çıtığı görülmüştür. Olumsuz anı gruplarında yönergesiz hatırlamanın duygu durumu olumlulaştırdığı gözlenirken (bkz. Şekil 1 ve Şekil 2), olumlu anı grubu katılımcılarının yönergesiz hatırlama sonrasında öncesine göre daha olumsuz bir duygu durum ifade ettikleri gözlenmiştir (bkz. Şekil 3).

2 Duygusal etki değişkeni, Öner ve Gülgöz (2017) makalesinde açıklandığı üzere hesaplanmıștır. Bu hesaplama için öncelikle öznel zaman algısı değerlendirmeleri 100'den çıkarılarak revize edilmiștir. Bunun nedeni, özgün yanıtlarda öznel zaman algısındaki düsük değerler algılanan yakınlığı temsil ederken, yüksek değerler anının ne kadar önce olduğuna dair uzaklığı temsil etmektedir. Anı yakın zamanda gerçekleşmiş gibi algılandıkça duygusal etkisi artacağından, duygusal etki hesaplamasında böyle bir yol kullanılmıștır. Elde edilen yeni öznel zaman puanları ile, anının -3'ten +3'e uzanan olumsuzluk- olumluluk eksenindeki değerlendirmeleri çarpıldığında duygusal etki puanına ulaşılmaktadır. Çalıșmadaki bir anıdan örneklersek, bugün olmuş gibi hatırlanan, öznel zaman algısına 0 verilen ve -3 ile çok olumsuz değerlendirilen bir anının duygusal etkisi -300 olarak kodlanmıştır. 
Tablo 2. Yönergesiz Anı Özellikleri

\begin{tabular}{lccc}
\hline & Üzüntü Anısı Grubu & Öfke Anısı Grubu & Mutluluk Anısı Grubu \\
\cline { 2 - 3 } & Ort. $(S)$ & Ort. $(S)$ & Ort. $(S)$ \\
\cline { 2 - 3 } Öznel zaman algısı & $62.12(32.13)$ & $63.22(26.57)$ & $54.48(32.95)$ \\
Olumsuzluk - Olumluluk & $0.89(1.82)$ & $0.66(1.47)$ & $-0.21(2.41)$ \\
Önem & $5.25(2.01)$ & $5.04(1.87)$ & $4.66(2.11)$ \\
Yeniden yaşama hissi & $4.43(1.96)$ & $4.59(1.75)$ & $4.45(1.87)$ \\
Duygusal yoğunluk & $3.96(2.17)$ & $4.20(1.81)$ & $4.00(1.82)$ \\
Görsel imgelem & $5.51(1.60)$ & $5.78(1.26)$ & $5.96(1.23)$ \\
Görsel perspektif & $2.86(2.37)$ & $3.33(2.12)$ & $3.15(2.19)$ \\
\hline
\end{tabular}

\section{Duygu Düzenlemeye Aracı Olan Anı Değişkenlerinin Test Edilmesi}

Duygusal etki düzeyinin yönergesiz hatırlama öncesinde ve sonrasında ölçülen duygu değişiminde etkili olduğu bulunmuştur. Özellikle belirgin olumlu anılar hatırlayan olumsuz anı grubu katılımcilarının duygu ifadelerinde olumluluk gözlenmiştir. Bu duygu durum değişimine aracılık eden yönergesiz hatırlama özelliklerini inceleyebilmek amaciyla hiyerarşik regresyon analizi uygulanmıştır. Temel olarak, hatırlama öncesi duygulanım ve ana aracı olan duygusal etkiyi kontrol ederek her bir grup için belirleyici olan anı özelliklerinin gösterilmesi amaçlanmıştır.

Yönergesiz anı sonrası duygulanımın bağımsız değişken olduğu analizlerde, ilk basamak bağımsız değişken olarak hatırlama öncesi duygulanım kullanılmıştır. İkinci basamakta ise yönergesiz anının duygusal etkisi kullanılmıştır. Üçüncü ve son basamakta ise yeniden yaşama hissi, duygusal yoğunluk, imgelem ve önem değişkenleri kademeli (stepwise) regresyona dahil ederek analiz uygulanmıştır. Beklendiği üzere, duygusal etkinin olumsuz anı gruplarında yönergesiz hatırlama için anlamlı bir belirleyici olduğu, ancak anı özellikleri devreye girdiğinde bu etkinin yok olduğu görülmektedir. Ayrıca üzüntü grubu için olumsuzluk - olumluluk ile yoğunluk temel yordayıcılar iken öfke grubu için olumsuzluk - olumluluk ile atfedilen önem yönergesiz hatırlamanın yarattığı olumlu duygu durumu açıklamaktadır. Tablo 2 regresyon modeline ilişkin bulguları detaylı olarak göstermektedir.

\section{Tartışma}

Otobiyografik hatırlamanın işlevsel kullanımının duygu düzenleme süreçlerinde önemli bir rol oynadığ 1 düşünülmekte ve özellikle olumsuz duygu durumu azaltmakta etkili olduğuna dair bulgular alanyazında giderek yaygınlaşmaktadır. $\mathrm{Bu}$ doğrultuda, yapılan çalışmada üzüntü ve öfke gibi olumsuz duyguların uyarılmasını takip eden hatırlama süreçlerinin duygu durumu değiştirmedeki etkisi incelenmiştir. Katılımcılardan öncelikle üzüntü, öfke ya da mutluluk uyandıracak anılar hatırlamaları istenmiş ve ardından o an hatırladıkları herhangi bir anıyı anlatmaları istenmiştir. Herhangi bir yönerge verilmeden hatırlanan anının olumsuz anı gruplarında bilinçdışı bir duygu düzenleme işlevine sahip olduğu ve anılarla uyandırılan olumsuz duygu durumu olumlulaştırmaya hizmet edeceği öngörülmüştür. Bu olumlulaşma yönelimine farklı mekanizmaların aracı olabileceği düşünülerek olumsuz duygular üzüntü ve öfke olarak ayr1larak bu gruplardaki etkili olacak hatırlama dinamikleri incelenmiştir. Başka bir deyişle, üzüntü ve öfke duygularıyla ilintili anıları oluşturan özellikler farklı olacağından (Uzer ve Gülgöz, 2014) bu anıların seyreltilmesi de birbirinden farklı hatırlama süreçleri gerektirebilir. $\mathrm{Bu}$ nedenle duygu durumun hatırlamaya bağlı değişimi ile beraber duygu düzenlemeye aracı olan yönergesiz anının özellikleri de incelenmiştir.

Bulgular incelendiğinde öncelikle beklendiği üzere, ilk aşamada hatırlanan üzüntü ve öfke uyandıran anılar mutlululuk anılarına göre daha olumsuz değerlendirilmiştir. Bu durum anı içerikleri ile tutarlı olsa da, anı özellikleri incelendiğinde duygusal yoğunluk, yeniden yaşama hissi ve imgelem gibi hatırlama özelliklerinde bir farklılık görülmemiştir. Oysaki güdüsel olarak öfke daha hızlı uyarılan ve keskin tepkiler doğurma eğiliminde olan bir duygudur. Bu nedenle özellikle anı canlılı̆̆ bağlamında üzüntü grubundan farklılaşması beklense de bulgular aksi yöndedir. Yönergesiz hatırlama deneyimi- 
Tablo 3. Üzüntü Anısı Regresyon Modeli

\begin{tabular}{|c|c|c|c|c|c|}
\hline & & Düzeltilmiş $R^{2}$ & $F$ & Beta & $p$ \\
\hline Model 1 & Duygu değişimi (1) ${ }^{\mathrm{a}}$ & -.02 & .23 & .07 & .64 \\
\hline \multirow[t]{2}{*}{ Model 2} & Duygu değişimi (1) ${ }^{\mathrm{a}}$ & \multirow[b]{2}{*}{.28} & \multirow[b]{2}{*}{$9.34^{* *}$} & -.04 & .78 \\
\hline & Duygusal etki & & & .54 & .00 \\
\hline \multirow[t]{3}{*}{ Model 3} & Duygu değişimi (1) ${ }^{\mathrm{a}}$ & \multirow{3}{*}{.50} & \multirow{3}{*}{$15.90^{* * *}$} & .02 & .82 \\
\hline & Duygusal etki & & & -.02 & .90 \\
\hline & Olumsuzluk - olumluluk & & & .72 & .00 \\
\hline \multirow[t]{4}{*}{ Model 4} & Duygu değişimi (1) ${ }^{\mathrm{a}}$ & \multirow{4}{*}{.57} & \multirow{4}{*}{$15.34^{* *}$} & .08 & .42 \\
\hline & Duygusal etki & & & -.07 & .63 \\
\hline & Olumsuzluk - olumluluk & & & .72 & .00 \\
\hline & Duygusal yoğunluk & & & .27 & .01 \\
\hline
\end{tabular}

Not 1. ${ }^{\text {a }}$ Önergesiz hatırlamadan önceki duygu değerlendirmesi

Not 2. ${ }^{* *} p<.01$

nin de bu bağlamda anı grupları arasında farklılaşmaması doğaldır.

Duygu durum ifadelerine bakıldığında, üzüntü ve öfke anıs1 gruplarındaki katılımcılar mutluluk anısı hatırlayan katılımcılara göre daha olumsuz hissettiklerini ifade etmişlerdir. Bu da ilk aşamadaki anı hatırlamanın beklendiği üzere anı içeriğindeki temel duygu ile tutarlı duygu uyardığını göstermektedir. Öte yandan, yönergesiz hatırlamadan sonra grupların duygu durum ifadeleri arasında bir fark gözlenmemiştir. Bu örüntü, olumsuz duygu gruplarındaki katılımcıların olası bir telafi mekanizması kullanarak olumlu duygu grubu ile eşdeğer bir duygu duruma eriştiklerine işaret etmektedir.

Yönergesiz hatırlama öncesi ve sonrası duygu durum ifadelerindeki değişim detaylı incelendiğinde, olumsuz duygu gruplarında yönergesiz anı hatırlama ile beraber hissedilen duygu daha olumlu hale gelmiştir. Olumlu anı hatırlayan grupta ise belirgin bir farklılık olmadığı ancak duygu durumdaki değişim eğiliminin olumluluğun artmasından ziyade azalması yönünde olduğu gözlenmiştir. Değişimdeki bu örüntüde iki temel durum söz konusudur. Bunlardan birincisi, duygu durumdaki olumlulaşma eğiliminin beklendiği üzere yalnızca olumsuz anı hatırlayan gruplarda görülmesidir. Faydacı bir yaklaşımdan (Mauss ve ark., 2007; Tamir ve ark., 2013) bakılacak olursa, duygu düzenlemenin ana amacı duygu değişimini dengelemek değil, duygulanımı hedefe yönelik değiştirebilmektir. Dolayısıyla kişiler yalnızca olumsuz duygular hissettiklerinde olumlu duygular hissetmeye daha çok eğilimli olacaklar, bu sayede de anıların tetiklediği olumsuz duygu ve düşünceleri telafi edebileceklerdir. Bununla ilişkili ikinci temel nokta ise mutluluk uyandıran anılar hatırladıktan sonra duygulanımda çok belirgin olmasa da bir düşüş gözlenmesidir. İlk aşamada en yoğun duygu yükü olan olumlu anılarını hatırlayan mutluluk anıs1 grubu katılımciları, her ne kadar olumlu hislerini korumaya yönelseler de ikinci aşamada hatırladıkları anının duygusal yoğunluğu daha düşük olduğundan yönergesiz hatırlama sonrasında olumlu duygularında bir düşüş gözlenmiş olabilir. Diğer bir olasılık ise olumlu duyguların uyarılmasından sonra bu olumlu duygulanıma kişilerin alışmış olması ve bu nedenle de yönergesiz anı olumlu olsa dahi öznel duygu ifadesine bu olumluluğun yansımamış olması olabilir. Bu olası açıklamaların ileriki çalıșmalarda kontrollü olarak incelenmesi yararlı olacaktır. Burada vurgulanmasının önemli olduğu düşünülen nokta şu ki, duygu düzenleme ile yalnızca olumsuz hisseden katılımcılarda hatırlama sonucunda duygu ifadelerinde olumlulaşma yönelimi gözlenirken bu örüntü duygu düzenleme gereksinimi olmayan mutluluk grubunda gözlenmemektedir.

Yönergesiz anının özellikleri incelendiğinde ise beklendiği üzere anlamlı farklılıklar gözlenmemiştir. Ancak daha önceki çalışmalarda da gösterildiği üzere tek bir anı özelliğinin değil de duygusal etkinlik gibi anının belirginliğini etkileyebilecek faktörlerin etkileşimli bir rol oynaması muhtemeldir (Öner ve Gülgöz, 2017). Her ne kadar anı grupları arasında, yönergesiz anının 
Tablo 4. Öfke Anısı Regresyon Modeli

\begin{tabular}{|c|c|c|c|c|c|}
\hline & & Düzeltilmiş $R^{2}$ & $F$ & Beta & $p$ \\
\hline Model 1 & Duygu değişimi (1)a & .13 & $7.48^{* *}$ & .38 & .01 \\
\hline \multirow[t]{2}{*}{ Model 2} & Duygu değişimi (1) ${ }^{\mathrm{a}}$ & .23 & $7.68^{* *}$ & .30 & .03 \\
\hline & Duygusal etki & & & .35 & .01 \\
\hline \multirow[t]{3}{*}{ Model 3} & Duygu değişimi (1) ${ }^{\mathrm{a}}$ & & & .31 & .01 \\
\hline & Duygusal etki & .48 & $14.95^{* *}$ & -.13 & .40 \\
\hline & Olumsuzluk - olumluluk & & & .69 & .00 \\
\hline \multirow[t]{4}{*}{ Model 4} & Duygu değişimi $(1)^{\mathrm{a}}$ & & & .39 & .00 \\
\hline & Duygusal etki & 52 & $* *$ & -.12 & .40 \\
\hline & Olumsuzluk - olumluluk & . & 10. & .60 & .00 \\
\hline & Önem & & & .26 & .03 \\
\hline
\end{tabular}

Not 1. ${ }^{\text {a }}$ Önergesiz hatırlamadan önceki duygu değerlendirmesi

Not 2. ${ }^{* *} p<.01$

olumlu - olumsuzluğu, canlılığ1 ya da öznel yakınlığ farklı olmasa da duygusal etki değişkeninin, yani anının olumlu olduğu kadar çok yakın zamanda olmuş gibi hissedilmesinin anlamlı bir farklılığı olduğu görülmüştür. Üzüntü ve öfke anısı hatırlayan katılımcılar, mutluluk anısı hatırlayan katılımcılara nazaran yönergesiz hatırlamada yakın zamanda olmuş gibi hissedilen olumlu anılar hatırlamışlardır. Bu demek oluyor ki, her ne kadar yönergesiz anının tekil özellikleri ilk aşamada hatırlanan anıya göre anlamlı olarak farklılaşmasa da, anının duygusal etkisi bütünsel olarak ele alındığında çok belirgin bir farklılık ortaya çıkmaktadır. Bu bütünsel bakış etkileşimsel öğeleri de dahil ettiğinden oldukça önemlidir. Hatırlanan olayın öznel yakınlık - uzaklık değerlendirmesi bellek sisteminde ne denli belirgin ve kolay erişilebilir olduğuna dair bir gösterge olarak anının duygusal etkisini belirlemektedir (Ayduk ve Kross, 2010) Benzer şekilde, önemli ve benlik ile alakalı anıların daha yakın zamanda gerçekleşmiş gibi algılandığını (Van Boven ve ark., 2010) ve bu psikolojik yakınlık vesilesiyle de canlılığını ve etkinliğini koruduğu düşünülmektedir (Davis, Gross ve Ochsner, 2011).

Sutin ve Robins (2008) görsel bakış açısını (visual perspective), öznel uzaklık algısı ile ilişkilendirerek, hatırlama esnasında anıyı deneyimliyormuş (fïst person, field perspective) gibi ya da dışarıdan izliyormuş gibi (third person, observer perspective) hatırlyor olmanın anının duygusal etkisini değiştireceğini öne sürmüştür. Aktör bakış açısından değil de gözlemci bakış açısından hatırlamak anının hem duygu yoğunluğunu hem de yeniden yaşama hissi, imgelem, önem gibi fenomenolojik özelliklerini de düşürmektedir (Berntsen ve Rubin, 2006; McIsaac ve Eich, 2002).

Burada vurgulanmak istenen, anının bellek sistemindeki temsilinin görsel bakış açısı ya da psikolojik uzaklık - yakınlık ile değişebilmesi ve bu değişimin, hatırlama deneyiminin etkisini farklılaştırabilmesidir. $\mathrm{Bu}$ nedenle, yönergesiz hatırlama öncesi ve sonras1 duygu durumundaki değişim duygusal etki değişkeni de değerlendirmeye alınarak incelendi. Öngörüldüğü üzere, daha olumlu ve yakın zamanda olmuş gibi anılar hatırlayan katılımcılar yönergesiz hatırlama sonrasında, öncesine nazaran daha olumlu duygular ifade etmişlerdir. Bu örüntü ise özellikle olumsuz anı gruplarında öne çıkmaktadır. Bu örüntü duygu durum değişimine aracı olan mekanizma hakkında bize önemli bilgi vermektedir. Öznel zaman algısı, anının ne denli canl,, belirgin ve kolay erişilebilir olduğuyla ilişkilidir (Lieberman ve ark., 2002). Dolayısıyla yalnızca olumlu anı hatırlayan değil de psikolojik yakınlığı yüksek olan olumlu anıları geri çağırabilen katılımcılarda duygu düzenleme mümkün olmuş ve olumsuz duygulanım seyreltilebilmiştir.

Üzüntü ve öfke duygularını oluşturan dinamiklerin farklı olduğundan yola çıkarak bu duyguların düzenlenmesinde farklı mekanizmaların etkili olabileceği düşünülmüştür. Örneğin, üzüntü, yoğunluğu düşük ve sürece yayılmış bir duygu iken; öfke, hızlı tepki doğuran, keskin ve yoğun bir duygudur (Kaplan, Van Damme ve Levine, 2012). Bu 
Tablo 5. Mutluluk Anısı Regresyon Modeli

\begin{tabular}{llcccc}
\hline & & Düzeltilmiş $R^{2}$ & $F$ & Beta & $p$ \\
\cline { 3 - 5 } Model 1 & Duygu değişimi (1) & .02 & 0.99 & .15 & .32 \\
Model 2 & Duygu değişimi (1) & & & .9 & .45 \\
& Duygusal etki & .43 & $17.99^{* *}$ & .66 & .00 \\
Model 3 & Duygu değişimi (1) & & & .03 & .80 \\
& Duygusal etki & .52 & $16.92^{* *}$ & .26 & .14 \\
& Olumsuzluk - olumluluk & & & .51 \\
\hline
\end{tabular}

Not 1. ${ }^{\text {a } Y o ̈ n e r g e s i z ~ h a t ı r l a m a d a n ~ o ̈ n c e k i ~ d u y g u ~ d e g ̆ e r l e n d i r m e s i ~}$

Not 2. ${ }^{* *} p<.01$

nedenle de, daha önceki çalıșmalarda gösterildiği gibi, imgelem ve yeniden yaşama hissi gibi değişkenlerin öfkenin düzenlenmesinde daha etkili olacağı düşünülmüștür (Öner ve Gülgöz, 2017). Üzüntü ve öfkenin düzenlenmesinde anı grupları yönergesiz anının canlılık özellikleri bağlamında farklılaşmamıştır. Bunun bir sebebi, öfke ve üzüntü duygularının uyarılmasından kişilerin aynı derece olumsuz hissediyor olması olabilir. Diğer bir sebebi ise analitik yöntem ile ilgili olabilir. Mutluluk, üzüntü veya öfke anısı gruplarında olumsuz ve olumlu duygu grupları (örn., üzüntü-mutluluk; öfke-mutluluk) olarak istatiksel karșılaştırmalar yapılsa görülebilecek etkiler, geniş varyans aralıkları nedeniyle tüm gruplar içerildiğinde ortaya çıkamıyor olabilir. Bununla beraber, üzerinde durulması gereken bizce en önemli konu duygu dinamikleri arasındaki farklardır. Üzüntü ve öfke olumsuz duygular olmakla beraber, öfke ve mutluluk ise heyecanlanma (arousal) düzeyi yüksek ve yaklaşma odaklı (approach-oriented) duygulardır (Lerner ve Keltner, 2000). Duyguların kavramsal ortaklıklarının yanı sıra, ilk hatırlama aşamasındaki anı özelliklerine bakıldığında da olumluluk - olumsuzluk dışında anılar, yeniden yaşama hissi, imgelem ve yoğunluk açısından farklılaşmamaktadır. Dolayısıylaanıları oluşturan temel duygu dinamikliklerindeki ortaklıklar, yönergesiz hatırlama sürecine yansıyarak yönergesiz hatırlama özelliklerini belirgin biçimde etkilememiştir. Ancak, bütünsel bakıldığında yönergesiz hatırlama olumsuz hisseden katılımcılar için duygu durumu olumlulaştırmaya hizmet etmiş ve buna da anının duygusal etkisinin aracı olduğu gözlenmiştir.

Öte yandan, duygusal etkinin her iki duygunun düzenlenmesinde benzer şekilde etkili olduğu gözlense de anının duygusal etkisi kontrol edilerek anı özelliklerinin rolü incelendiğinde, duygusal etkinin yönergesiz anının farklı özelliklerini etkileyerek değişime neden olduğu bulunmuştur. $\mathrm{Bu}$ örüntü oldukça anlamlıdır. Üzüntü anıs1 grubunda yönergesiz hatırlamadan sonraki duygu durumu belirleyen duygusal etki iken, anının duygusal yoğunluğu devreye girdiğinde bu etki kaybolmaktadır. Yönergesiz anıyı daha olumlu ve yakın zamanda olmuş gibi hatırlamak anının duygusal yoğunluğunu da beraberinde artırmış ve bu sayede de kişiler daha olumlu duygular ifade etmişlerdir. Öfke anısı grubunda ise benzer mekanizma yönergesiz anıya atfedilen önemi artırmış, bu da anının duygu olumlayıcı işlevini desteklemiştir.

\section{Duygu Düzenleme Yöntemleri Olarak Bilişsel Yeni- den Değerlendirme ve Uzaklaştırma}

$\mathrm{Bu}$ çalışmanın alt amaçlarından biri en etkili duygu düzenleme yöntemlerinden biri olan bilişsel yeniden değerlendirmenin (Gross, 2015; Mauss, Cook, Cheng ve Gross, 2007; Webb, Miles ve Sheeran, 2012) belleğin duygu düzenleme işlevi esnasındaki rolünü incelemekti. Bilişsel yeniden değerlendirme denince, duyguların şiddetini ve niteliğini değiştirmek için duygu yaratan olayı değil de o olayın anlamını duygusal tepkiyi düzenleyecek biçimde değiştiren süreçler akla gelmektedir (McRae ve ark., 2012). Alanda yapılan birçok çalışmada bilişsel yeniden değerlendirme incelenirken aktif olarak katılımcılardan duygusal uyarıcıları daha olumlu olacak biçimde yorumlamaları istenmiştir. Haliyle bulgular ağırlıklı olarak bilinçli ve kontrollü duygu düzenleme süreçlerine dayanmaktadır. Ancak istemsiz işleyen bilişsel yeniden değerlendirmenin yönetildiği bilişsel mekanizmaların ve etkisinin istemli, kontrollü yorumlama çabalarından farklı olduğu düşünülmektedir (Feldman ve Barrett, 1997). Bu çalışmada hedeflenen bir yönerge olmaksızın belleğin duygu düzenleme amaçlı kullanılması olduğundan, bilişsel yeniden değerlendirmeyi incelerken açıkça duygu düzenleme vurgusu yapılmamıştır.

İlk aşamada üzüntü ve öfke içerikli anı hatırlayan olumsuz anı gruplarında, bilişsel yeniden değerlendirme yatkınlığı yüksek olan bireylerin, yönergesiz hatırlama 
sonrasında daha yüksek bir olumlama eğilimi göstereceğini bekliyor olsak da bulguların bu yönde olmadığ görülmüştür. Dahil edildiği analizlerde bilişsel yeniden değerlendirmenin bulguların örüntüsünü etkilemediği tutarlı olarak gösterilmiştir. Bu oldukça önemlidir, çünkü bireylerin deneyimlerini yorumlaması kendiliğinden gelişen, otomatik bir süreç iken, anıların yeniden yorumlanması önemli ölçüde bilişsel çaba gerektirmektedir. Bireylerarası farklılıkların ard arda hatırlama süreçlerine yansımaması olasıdır. Örneğin, birey günlük hayatında bilişsel yeniden değerlendirmeyi sıkça kullanıyor olsa bile, hatırlanan anının duygusal yükü, istemli duygu düzenleme süreçlerini engelliyor olabilir. Benzer şekilde, mutluluk anı grubunda bilişsel yeniden değerlendirme yatkınlığı yüksek bireyler olsa bile, bu katılımcılar duygu düzenlemeye ihtiyacı olmayacağından gruplar arası farklılık oluşmuyor olabilir.

Öznel zaman algısı anının benlik için ne denli merkezi olduğunun göstergesi olduğundan, bu zaman algısındaki düzenlemelerin anıyı benlikle daha az ya da çok ilişkili kıldığı ve sonucunda da anının duygusal etkisini de belirlediği daha önce de bahsedilmiștir (Ayduk ve Mischel, 2011; Van Bowen ve ark., 2010; Wilson ve Gilbert, 2008). Anıları hatırlarken çok zaman önce olmuş gibi hatırlamanın yani psikolojik uzaklığın aslında bilișsel yeniden değerlendirmenin bir parçası olduğu düşünülmektedir (Gross, 1998; Kross ve Ayduk, 2016; McRae ve ark., 2012). Başka bir deyişle, anılar için psikolojik uzaklığın fazla hissedilmesi, hatırlama deneyimindeki duygusal yoğunluğu seyreltmekte ve bu süreç oldukça otomatik olarak gerçekleşmektedir (Ayduk ve Kross, 2010; Trope ve Liberman, 2010). Dolayısıyla kişilerin ölçek değerlendirmeleri üzerinden ölçülen bilişsel yeniden değerlendirme yetisinin değil de anıların psikolojik yakınlık - uzaklık kavramının bu bağlamda daha etkin bir duygu düzenleme yöntemi olarak kullanıldığı açıktır.

Buradan çıkarılacak önemli sonuçlardan biri, bilişsel yeniden değerlendirme incelenirken yöntemsel araçların amaca uygun seçilmesindeki gerekliliktir. Bu çalışmada olduğu gibi belirli bir yönerge olmaksızın genel yatkınlığın incelemesi, bilişsel yeniden değerlendirmenin o durumda kullanılıp kullanılmadığına dair bilgi vermeyecektir. Ayrıca bilişsel yeniden değerlendirme bütün olarak yeniden yorumlama süreçlerini kapsıyor olsa da farklı mekanizmalar ile yürütülebilir (McRae ve ark., 2012). Dolayısıyla öznel zaman algıs1 gibi belirli yöntemleri incelemenin daha net sonuçlara ulaştıracağı düşünülmektedir.

\section{Sonuç ve Öneriler}

Araştırma bulguları belleğin duygu düzenleme işlevinin deneysel olarak gösterilmesi bağlamında alan- yazına önemli katkı sağlamaktadır. Bu araştırmada birtakım k1sıtlılıklar da söz konusudur. Bunlardan birincisi her ne kadar katılımcılardan üzgün, öfkeli ya da mutlu hissettiren anılar hatırlamaları istense dahi ilk hatırlama aşamasından sonra kişilere ne denli üzgün, öfkeli ya da mutsuz hissettikleri değil ne denli olumlu - olumsuz hissettikleri sorulmuştur. Kimi olaylarda duygular iç içe olabilir ve özellikle olumsuz duygu grupları için bu duyguların bir arada olması sonraki hatırlama deneyiminde belirgin farklılıklar görülmemesine neden olmuş olabilir. Dolayısıyla farklı duyguların nasıl düzenlendiğini anlamak amaçlandığında, öncelikle istenen duygunun ne denli uyarıldığını anlamak anı gruplarının doğru ayrıştığını teyit etmek açısından daha güvenilir olacaktır.

Başka bir kısıtlılık ise öznel zaman algısının ilk hatırlanan anılar için sorulmamasıdır. Yönergesiz anıda olduğu gibi duygusal etki bu ilk aşamada hatırlanan duygu yüklü anıların etkisi de psikolojik yakınlık-uzaklik çerçevesinde değişebilir ve bu da sonraki yönergesiz hatırlama sürecinde farklılık yaratabilir. Dolayısıyla sonraki çalıșmalarda bu değişkenin ele alınması bulgular konusundaki yorumları güçlendirecektir.

Son olarak, katılımcılar her ne kadar ilk hatırlamada oldukça negatif buldukları olaylar hatırlamış olsalar da, duygu durumları sorulduğundaki değerlendirmeleri olumsuz anı gruplarında olumsuz - nötr arasında bir yere karş1lık gelmektedir. Bunun iki sebebi olabilir. Birincisi, bilinç düzeyindeki duygu değerlendirmesi, anının olumsuz - olumlu oluşuyla tam bir paralellik göstermeyebilir. Başka bir nedeni ise hatırlamanın anlık duygu durumu değiştirmekte yeterince etkin olmaması olabilir. Bu da duygu uyandırma için hatırlama süreçlerinin yeterince etkin olmadığını düşündürebilir. Buna rağmen, olumsuz anı grubu katılımcılarının hatırlama öncesi ve sonrasındaki duygu durumlarının olumsuzdan olumluya değiştiği göz önüne alındığında bulguların örüntüsü anlamını koruyacaktır.

$\mathrm{Bu}$ kısıtlılıklara rağmen çalışmanın bulguları açıkça, herhangi bir duygu düzenleme yönergesi verilmeksizin olumsuz hisseden bireylerin otobiyografik hatırlamay1 kullanarak daha olumlu hissettiklerini ve bu değişime de öznel zaman etkisinin aracılık ettiğini, göstermektedir. $\mathrm{Bu}$ alanda yapılacak sonraki çalışmalarda resim ve video gibi farklı duygu uyarım yöntemleri kullanılabilir; üzüntü ve öfke dışında tiksinme, kaygı gibi diğer olumsuz duygular da incelenebilir. Elde edilecek bulguların da belleğin duygu düzenleme işlevinin ve arac1 mekanizmaların anlaşılması açısından oldukça yararlı olacağı düşünülmektedir. 


\section{Kaynaklar}

Alea, N. ve Bluck, S. (2003). Why are you telling me that? A conceptual model of the social function of autobiographical memory. Memory, 11, 165-178.

Alea, N. ve Bluck, S. (2007). I'll keep you in mind: The intimacy function of autobiographical memory. Applied Cognitive Psychology, 21(8), 1091-1111.

Ayduk, O. ve Kross, E. (2010). From a distance: Implications of spontaneous self-distancing for adaptive self-reflection. Journal of Personality and Social Psychology, 98(5), 809-829.

Bargh, J. A. ve Williams, L. E. (2007). The nonconscious regulation of emotion. J. J. Gross (Ed.) Handbook of emotion regulation içinde (429-444). New York: Guilford Press.

Bluck, S., Alea, N., Habermas, T. ve Rubin, D. C. (2005). A tale of three functions: The self-reported uses of autobiographical memory. Social Cognition, 23(1), 91-117.

Bluck, S., Alea, N. ve Demiray, B. (2003). You get what you need the psychosocial functions of remembering. J. H. Mace (Ed.), The act of remembering: Toward an understanding of how we recall the past (3. cilt) içinde (284-386). John Wiley \& Sons.

Bluck, S. ve Habermas, T. (2000). The life story schema. Motivation and Emotion, 24(2), 121-147.

Conway, M. A. (2005). Memory and the self. Journal of Memory and Language, 53, 594-628.

Demiray, B., Gülgöz, S. ve Bluck, S. (2009). Examining the life story account of the reminiscence bump: Why we remember more from young adulthood. Memory, 17(7), 708-723.

Gross, J. J. (2002). Emotion regulation: Affective, cognitive, and social consequences. Psychophysiology, 39, 281-291.

Gross, J. J. ve Levenson, R. W. (1997). Hiding feelings: The acute effects of inhibiting negative and positive emotion. Journal of Abnormal Psychology, 106(1), 95-103.

Gross, J.J. ve John, O.P. (2003). Individual differences in two emotion regulation processes: Implications for affect, relationships, and well-being. Journal of Personality and Social Psychology, 85, 348-362.

Gülgöz, S. ve Rubin, D. C. (2001). Kişisel anıların hatırlanması: bir betimleme çalışması. Türk Psikoloji Dergisi, 16, 37-55.

Koole, S. L. (2009). The psychology of emotion regulation: An integrative review. Cognition and Emotion, 23(1), 4-41.

Koole, S. L. ve Fockenberg, D. A. (2011). Implicit emotion regulation under demanding conditions: The moderating role of action versus state orientation.
Cognition and Emotion, 25(3), 440-452.

Liberman, N., Sagristano, M. D. ve Trope, Y. (2002). The effect of temporal distance on level of mental construal. Journal of Experimental Social Psychology, 38(6), 523-534.

Mauss, I. B., Cook, C. L. ve Gross, J. J. (2007). Automatic emotion regulation during anger provocation. Journal of Experimental Social Psychology, 43(5), 698-711.

Neisser, U. (1978). Memory: What are the important questions? M. M. Gruneberg, P. E. Morris, R. N. Sykes (Ed.), Practical aspects of memory içinde (3-19). London: Academic Press.

Nezlek, J. B. ve Kuppens, P. (2008). Regulating positive and negative emotions in daily life. Journal of Personality, 76(3), 561-580.

Nolen-Hoeksema, S. ve Morrow, J. (1991). A prospective study of depression and post- traumatic stress symptoms following a natural disaster: The 1989 Loma Prieta Earthquake. Journal of Personality and Social Psychology, 61(3), 115-121.

Öner ve Gülgöz (2018). Autobiographical remembering regulates emotions: A functional perspective. Memory, 26, 1, 15-28.

Pasupathi, M. (2003). Emotion regulation during social remembering: Differences between emotions elicited during an event and emotions elicited when talking about it. Memory 11(2), 151-163.

Pillemer, D. (2003). Directive functions of autobiographical memory: The guiding power of the specific episode. Memory, 11(2), 193-202.

Raes, F., Hermans, D., de Decker, A., Eelen, P. ve Williams, J. M. G. (2003). Autobiographical memory specificity and affect regulation: An experimental approach. Emotion, 3(2), 201-206.

Rasmussen, A. S. ve Berntsen, D. (2009). Emotional valence and the functions of autobiographical memories: positive and negative memories serve different functions. Memory \& Cognition, 37(4), 477-492.

Richards, J. M. ve Gross, J. J. (2000). Emotion regulation and memory: The cognitive costs of keeping one's cool. Journal of Personality and Social Psychology, 79(3), 410-424.

Richards, J. M., Butler, E. A. ve Gross, J. J. (2003). Emotion regulation in romantic relationships: The $\operatorname{cog}$ nitive consequences of concealing feelings. Journal of Social and Personal Relationships, 20(5), 599-620.

Richards, J. M. ve Gross, J. J. (2005). Personality and emotional memory: How regulating emotion impairs memory for emotional events. Journal of Research in Personality, 40(5), 631-651. 
Rubin, D. C., Schrauf, R. W. ve Greenberg, D. L. (2003). Belief and recollection of autobiographical memories. Memory \& Cognition. 31, 887-901.

Rubin, D. C. ve Berntsen, D. (2003). Life scripts help to maintain autobiographical memories of highly positive, but not highly negative, events. Memory \& Cognition, 31(1), 1-14.

Sheppes, G. ve Gross, J. J. (2011). Is timing everything? Temporal considerations in emotion regulation. Personality and Social Psychology Review, 15(4), 319-331.

Schwager, S. ve Rothermund, K. (2013). On the dynamics of implicit emotion regulation: Counter-regulation after remembering events of high but not of low emotional intensity. Cognition \& Emotion, 1-22.

Talarico, J. M., LaBar, K. S. ve Rubin, D. C. (2004). Emotional intensity predicts autobiographical memory experience. Memory \& Cognition, 32(7), 1118-1132.

Tamir, M., Ford, B. Q. ve Gilliam, M. (2013). Evidence for utilitarian motives in emotion regulation. Cognition \& Emotion, 27(3), 483-491.

Trope, Y. ve Liberman, N. (2010). Construal-level theory of psychological distance. Psychological Review, $117(2), 440-463$.

Tulving, E. (1986). Episodic and semantic memory: Where should we go from here? Behavioral and Brain Sciences, 9(3), 573-577.

Van Boven, L., Kane, J., McGraw, A. P. ve Dale, J. (2010). Feeling close: Emotional intensity reduces perceived psychological distance. Journal of Personality and Social Psychology, 98(6), 872.

Uzer, T. ve Gülgöz, S. (2015). Socioemotional selectivity in older adults: Evidence from the subjective experience of angry memories. Memory, 23(6), $888-900$.

Yurtsever, G. (2004). Emotional regulation strategies and negotiation. Psychological Reports, 95, 780-786.

Waters, T. E., Bauer, P. J. ve Fivush, R. (2014). Autobiographical memory functions served by multiple event types. Applied Cognitive Psychology, 28(2), $185-195$.

Watson, L. A. ve Dritschel, B. (2015). The role of self during autobiographical remembering and psychopathology: Evidence from philosophical, behavioral, neural, and cultural investigations. L. A. Watson ve D. Berntsen (Ed.) Clinical Perspectives on Autobiographical Memory içinde (335-358). Cambridge University Press.

Wisco, B. E. ve Nolen-Hoeksema, S. (2010). Valence of autobiographical memories: The role of mood, cognitive reappraisal, and suppression. Behaviour Research and Therapy, 48(4), 335-340. 


\section{Summary Emotion Regulation Function of Autobiographical Remembering}

\author{
Sezin Öner \\ Kadir Has University
}

\author{
Sami Gülgöz \\ Koç University
}

\begin{abstract}
Although there has been extensive evidence on how and why emotions influence memory processes (i.e. Buchanan, 2007; Holland \& Kensinger, 2010), evidence is much less consistent on the way autobiographical remembering influence emotional states. Emotions may act as internal cues that trigger the retrieval of particular memories, which subsequently transforms the emotional state along with the individual's goals and expectations. As in this case, autobiographical remembering acts as a means that individuals may use, even without awareness, to alleviate the content and intensity of their emotional experiences.
\end{abstract}

\section{The Role of Autobiographical Remembering in Emotion Regulation}

The functional approach to autobiographical memory (Bluck et al., 2005) emphasized the why aspect of remembering rather than performance and accuracy-related aspects of what and how. According to this view, remembering serves three psychosocial functions, maintaining self-consistency and positive self-view over time (self-function), developing and maintaining social relationships (social function), and reflecting back and forth to guide current and future behaviors (directive function) (Bluck et al., 2005).

In the present research, we have focused on a specific aspect of self-function, emotion regulation, which basically refers to the modulation of memory processes in line with the regulatory goals to alleviate emotional states (Pasupathi, 2003). In doing so, remembering can be altered in a number of ways, either by changing what is remembered or the way it is remembered. Reminiscing on the positive instances (Walker, Skowronski, Gibbons, Vogl, \& Ritchie, 2009) and increasing the psychological distance of negative experiences help to down-regulate negative affect (Schwager \& Rothermund, 2013) whereas specific memories of negative events lead to intensify- ing the negative emotions. On the other hand, retrieval of memories in an overgeneral way reduces the subsequent effective change (Williams et al., 2007).

It is important to note that regulation does not necessarily aim feeling better. Individuals may attempt to decrease positive affect or increase negative affect as well. High cognitive avoidance was related to less specific retrieval of positive memories, serving these individuals to maintain self-consistency, and to regulate their emotions. Similarly, remembering a vivid scene of a negative event may help the individual to think over and resolve the emotional conflict associated with the event. In that sense, what determines the way regulation would function is the interaction between the individual's habitual regulatory behaviors and goals for emotion regulation in a particular context (Opitz et al., 2012).

Despite considerable theoretical discussions on the ways autobiographical remembering serves emotion regulation, existing evidence relies mostly on the variation in the way memories are retrieved, which is supposedly moderated by emotion regulation. It has been consistently argued that positive events tend to be perceived as more important, more self-relevant, as well as containing more detail and feelings of reliving (Berntsen, 2002; D'Argembeau \& Van der Linden, 2006; Rasmussen \& Berntsen, 2009; Rubin et al., 2003). The salience of positive experiences may serve to enhance one's adaptation to life and maintain a positive self-view, which has been considered to serve emotion regulation (Gross \& John, 2003; Nezlek \& Kuppens, 2008). However, we argue that these findings do not necessarily indicate that individuals are regulating their emotions using their autobiographical memories, but rather, it is as likely that the overall outcome (i.e. well-being) is a by-product of linked mechanisms in which emotion regulation and remembering are also involved. Such mechanisms may include rumination and cognitive avoidance, the trait-level

Address for Correspondence: Assoc. Prof. Sezin Öner, Kadir Has University, Faculty of Economics, Administrative and Social Sciences, Department of Psychology, Kadir Has Caddesi Cibali - Fatih / İstanbul

E-mail: sezin.oner@khas.edu.tr 
individual differences that have been widely studied and which have been associated with different retrieval characteristics. In the case of rumination, highly ruminating individuals were found to perceive negative events as more important, engage in frequent reminiscing, and remember especially negative events in an intense and vivid manner (Ayduk \& Kross, 2008; Nolen-Hoeksema, Wisco, \& Lyubomirsky, 2008; Schoofs, Hermans, \& Raes, 2012).

\section{Method}

\section{Participants}

We recruited a total of 144 adults $\left(M_{\text {age }}=39.46, S D\right.$ $=11.88 ; 116$ female) using the Koç University subject pool. Participants were randomly assigned to one of the three groups to recall sadness-inducing, anger-inducing, happiness-inducing memories. Whereas sadness and anger memory groups constituted the negative memory groups, the happy memory group acted as the positive memory control group.

\section{Measures}

Autobiographical Memory Experience (AMQ). For the emotion induction episode, participants were asked to remember two sadness, -anger-, or happiness -relevant- events. For each event, they rated the valence and recollective properties (i.e. reliving, imagery and emotional intensity) of the event on the Autobiographical Memory Questionnaire (Rubin et al., 2003). Similarly, for the subsequent recall, re-collective properties and important features were rated on AMQ as well. We also asked for the psychological distance with an item ("How far away does the event feel?") and participants indicated the psychological distance of the event on a continuum using a slider with values ranging from 100 ("I feel like the event happened today") to 0 ("I feel like the event occurred a very long time ago") (Demiray \& Janssen, 2014; Liberman, Sagristano \& Trope, 2002). Then, they provided the actual date of the event for the reported memory.

Pre- and post-report emotionality. We asked individuals how they were feeling before and after the subsequent remembering phase in order to evaluate the influence of autobiographical remembering on their emotional state. They indicated their responses on a 7-point scale in which lower scores represented the negative affect and higher scores represented positive affect.

Emotion Regulation Questionnaire. This 10-item measure of emotion regulation aims to assess individual differences in their habitual use of two emotion regulation strategies, cognitive reappraisal, and expressive suppression (Gross \& Thompson, 2003).

\section{Procedure}

Participants first responded to demographic information questions such as gender and age, then they were assigned to one of the sad, anger and happy memory groups. The specific instructions were as follows:

"We want you to think back to two events that made you feel lonely, sad, rejected, or hurt (and angry, annoyed or enraged for the anger memory group; happy, or proud for the happy memory group) in the last five years of your life. We would like you to recall these events in detail, remembering how you felt and what happened. Please make sure these are the events that you still feel emotional as you recall now. Take your time to recall the incidents and provide a brief description of each of them."

After participants reported each event, they rated their memory on the memory characteristics, which were valence, intensity, importance, imagery, and psychological distance and then they dated the event. Following the initial memory recall phase, we had a manipulation check to ensure that autobiographical remembering induced negative effect. In the subsequent recall phase, we requested one random memory, asking specifically "to recall an event that came to your mind. It could be related to anything but it should be an important, specific event that you experienced". For this, any memory, participants rated all the items in the AMQ and dated the event as well. As the last phase of the study, they reported their emotionality and completed the ERQ.

\section{Results and Discussion}

Changes in emotionality ratings became more salient, in that, individuals who recalled negative events in the initial recall, thus, who were feeling negative, which supported for a counter-regulation account. This is important as we did not expect efforts for emotion regulation in individuals who were feeling positive. The emotional impact of the subsequent recall had a significant role as well. Memories who were positive and perceived to occur in the near past had the most influence to upregulate positive emotions. Although we did not find any difference in the phenomenological features of the subsequent recall, there are subtle differences which appeared to be significant as we controlled for the emotional impact of the subsequent memory.

More specifically, for the sadness group, the emotional impact of the memory operated through the emotional intensity of the event, which resulted in high impact positive events in the subsequent recall to be perceived more emotionally intense and led to feeling more positive afterward. For the anger group, on the other hand, importance accounted for the role of emotional im- 
pact in the upregulation of positive effect. These findings are significant as we found evidence supporting the role of particular phenomenological features in the regulation of specific emotions.

Although we provided no explicit instructions to regulate emotions, we found that individuals who are better equipped with regulatory skills automatically oriented to the information in accordance with the emotion goals and remembering experience served to upregulate positive emotions. Previous studies also discussed the implicit (Koole, 2009) or covert (Aldao \& Dixon-Gordon, 2014) emotion regulation strategies both of which emphasized the automatic mechanisms that generation and regulation of emotions operate. We consider such a perspective as important because emotional processing in their daily life is mostly spontaneous; otherwise, continuous attempts to monitor and regulate emotions would be mentally exhausting.

In conclusion, the general idea we argue for is that emotion regulation function of autobiographical memory ensures a/the phenomenological form of the memory to be constructed to optimize regulation success. The events that are represented in the optimal phenomenology for an effective change are more likely to be retrieved, especially in individuals with effective regulatory skills. In that sense, current evidence has promising implications, showing what we remember is not that random, but interacts with both our internal states and the ways we use to regulate internal states. 